BEFORE / NOW

Vol. 1 No. 1

KEYWORDS

Bendigo; goldfields; gaol construction; gaol conditions; panopticon; Chinese. (c) The Author(s) [2019]

Published by the Collaborative Research Centre in Australian History, Federation University Australia. All rights reserved.

\section{The Gaol on the Hill: The prelude to and construction of Bendigo's sandstone gaol.}

\author{
Leigh Edmonds
}

\begin{abstract}
The gold rushes on the Victorian goldfields of the 1850s increased the population of the new colony seven times over. This created many problems for the new government, not the least of which was an increase in lawlessness which put authorities under severe pressure to house the rapidly growing convict population. Other issues confronting colonial prison administrators were the mobility of the population as gold seekers moved to the latest finds, the presence of a large Chinese population on the goldfields and the housing of the mentally disturbed. At the same time, new philosophies in prison design gave the Victorian government the potential to replace its first, hastily constructed, goals with the latest 'state of the art' prisons at strategic locations across the goldfields.
\end{abstract}

\section{Introduction}

The people who lived in the past left us mementos of their lives and times. Sometimes they have no physical existence, being the stories that are told about what happened in the past. Other times the mementos take a physical form such as the artefacts, structures and signs left in the landscape of the activities of past generations. Our understanding of past people and events usually combines both the physical and nonphysical manifestations of the past so that we tell stories about the physical things we find left to us from the past to give them significance. This article is one example of story telling that enhances understanding of something physical.

The large and impressive structures of Victoria's gold rush era stone goals demand to have their stories told due to their continuing physical presence. And, while their size and permanence might demand simple explanations for the casual viewer, built into these structures are complex accounts of the period during which they were designed and built, the people who built them and their understandings of their world. This account of the construction of the stone goal that still dominates the cityscape of Bendigo helps to explain how and why it takes the form it does.

This article is based on the premise that, while structures such as the Bendigo Gaol can tell a story through their physical manifestation alone, a fuller understanding of them can only be gained by reading the words of the people who made the decision to build these gaols, those who designed and built them and the officials who operated them. This was done in the reading room of the Public Records Office Victoria in an exploration of the records of the design, construction and early operation of the Bendigo Gaol.

Most prison history is written as social history around the lives of the inmates of these establishments. However, their lives are given shape by the physical forms of the places in which they are kept captive and the ways in which their lives are regulated by the people who operate them. That is an important aspect of understanding the 
totality of gaol experience so consequently this narrative history begins first with the political response to the penal problems associated with the rapid expansion of the Colony of Victoria during the gold rush era and then the administrative response that built into physical form the then most modern thinking about how those convicted of crimes should be treated. The result has been a lasting memento to one aspect of life in colonial Victoria at the end of the 1850s.

\section{Impermanent imprisonment}

Little remains physically to tell about the treatment of prisoners during the period that began with the white invasion of what is now Victoria in the 1830s until the construction of the stone goals in the late 1850s and early 1860s. This is due to the relatively limited extent of the white incursion until the gold rushes of the 1850s and then the temporary and shifting nature of white settlement in the first years of the gold rush era.

Pastoralists came to the land around the Loddon River in 1840 and established sheep runs there. For a decade, wool was the source of wealth from the area but in July 1851 a hut-keeper on one of the runs said he had found gold. The official discovery of gold on the Bendigo Creek was made in October of that year.

The 1850s was a golden age for Victoria. The colony was granted self-government in 1851 and a series of gold discoveries beginning at the same time made it an exciting and rich place to be. In 1850 there had been only 77,000 people in Victoria but the lure of gold brought people in their thousands. By 1857 the Victorian population had grown to 460,000 and by the beginning of the 1860 s it was 540,000 . For every one person living in Victoria in 1850 there were seven people only ten years later.

This extraordinary growth gave the new government many problems. One of the most important and difficult was that of providing law and order on the goldfields

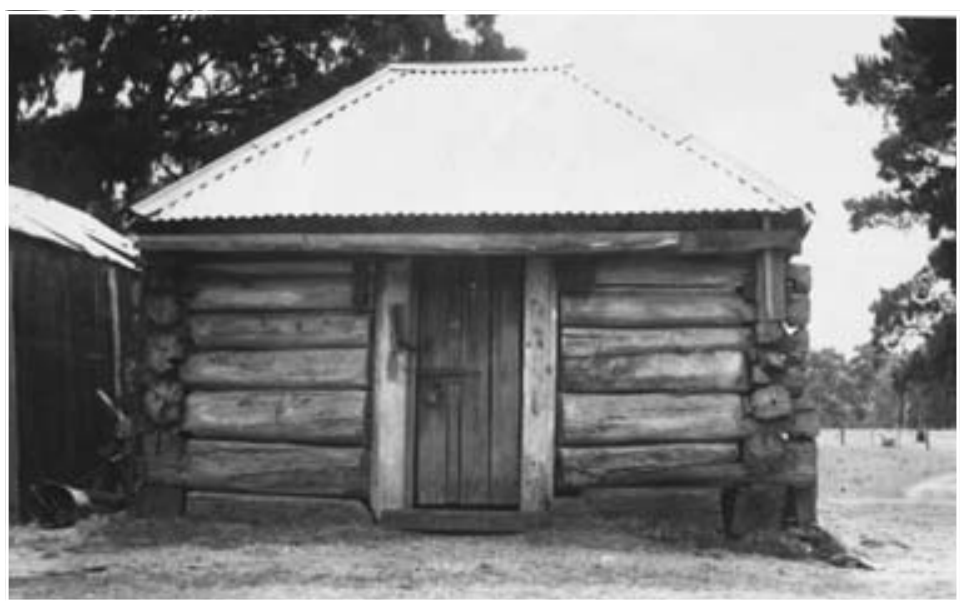

An old chock [?] and log building which was used in the 1850s as a gaol for gold stealers when the Bendigo diggings first started, [picture] 1934. State Library Victoria (SLV) Picture Collection, H19939. because thousands of people moved quickly from discovery to discovery as they were made. A place that had been swarming with people one month could be vacant the next and the government had to keep up with them. It did this by creating a mobile form of administration called the Government Camp that could move from goldfield to goldfield just as quickly.

By August of 1852 there were an estimated 50,000 people on the goldfield around Bendigo and south to Mount Alexander. ${ }^{2}$ To administer the people on the Bendigo Creek a Government Camp was set up on rising ground that looked down over the diggings and the creek winding across the plain below. The reserve was on about seventy acres (28.3 hectares) of bare sandstone rock on which a few ironbark trees struggled for existence. In it were the Police Court, Commissioner's Quarters, offices, police quarters, stables for horses and a lockup. The stables were made out of bark, the lockup was built of logs with a roof of bark and everything else was canvas. ${ }^{3}$ Police came down from the Camp onto the goldfields to enforce the gold licence fee that caused so much anger among the miners and was a major cause of the Eureka 
BEFORE I NOW

Vol. 1 No. 1

rebellion on the Ballarat goldfields in December 1854. Miners without a licence were taken up the hill for a quick hearing in the court and a visit to the lockup, commonly called 'The Logs'.

A permanent settlement gradually formed on the plain below the camp. Land for a town was surveyed, the first blocks were sold in April 1854 and all the allotments in the town centre had been sold by October the following year. Members of the first council of the Municipality of Sandhurst (named after the military establishment in England) were elected in January 1856. ${ }^{4}$ By April 1857 the population of the municipality had grown to $12,159 .{ }^{5}$

The government had to improve the services and facilities it provided for the growing population and creating better links with Melbourne became an important priority. Roads and bridges were constructed so a trip that had taken days in 1852 was reduced to only hours by 1856. The Cobb \& Co coach that left the Shamrock Hotel at half-pasttwo in the afternoon six days a week arrived in Melbourne early the following afternoon. The fare was $£ 6$, then a vast sum. ${ }^{6}$ Within a year, in January 1857, a telegraph line was opened between Melbourne and Sandhurst and a railway line was opened in October 1862. Travel time was reduced to four-and-a-half hours and fares dropped to $£ 2 / 7 / 3$ for a first class and $£ 1 / 14 / 9$ for a second class return trip.?

The gold rushes brought a severe increase in crime to Victoria. Thousands came to the goldfields hoping to get rich from gold but few did. One estimate suggested that 40 per cent left the diggings having made a living or a little more, twenty-five per cent left having made over $£ 50$, another twenty-five per cent left having gained nothing and ten per cent lost everything. ${ }^{8}$ Inevitably, some of them turned to crime to survive.

Some criminals also came to Victoria intending to exploit the new society and there were many convicts who had been transported from Britain with no chance of returning home. The Victorian gold fields gave them new opportunities and while there had been only 29 convictions in the Victorian Supreme Court in December 1851, there were 279 in December 1852 and 652 in December 1853. ${ }^{9}$ Many more people were convicted of less serious crimes and, in March 1853, about forty people a day were being sentenced to short terms in the Melbourne Gaol for nothing more serious than vagrancy. ${ }^{10}$

Victoria had to create a prison system to cope with this crime wave. There were no gaols in Victoria when it was separated from New South Wales in 1851 but by June 1852 there were five gaols, three in Melbourne and one each in Portland and Geelong. Soon another gaol was created at Pentridge, a temporary stockade to accommodate prisoners working on building the road to Sydney." These facilities could barely cope with the need and, in January 1853, the governor of Victoria's biggest gaol reported he had 385 prisoners and overcrowding was so bad that men were sleeping in the corridors, eight were sleeping in cells designed for three and three in cells designed for one..$^{2}$ The situation rapidly got even worse and by the middle of the year the government had put us stockades at Collingwood and Williamstown and begun buying derelict ships that it converted into prison hulks to accommodate the exploding prison population. The stockade at Pentridge was quickly expanded and it became the centre of Victoria's prison system. ${ }^{13}$

There were no gaols on Victoria's goldfields until late 1853. It appears they were established as the result of an investigation into the state of the prison system and the following decision to establish gaols at the most important population centres on the 
goldfields. They were placed under the control of the deputy-sheriffs in each locality but the penal department in Melbourne provided key staff members and the 'General Rules for Gaols' of 1853 that they operated under..$^{14}$ One of the new country gaols was established at Sandhurst in the Government Camp reserve, overlooking the growing town.

\section{The Sandhurst Stockade}

The prison stockade at Sandhurst was proclaimed a 'public gaol' on 20 December 1853. It was described as 'consisting of Four Block Houses enclosed by a Stockade'.15 Joseph Wilson Gee was appointed its first governor. Since the new gaol would accommodate both men and women prisoners a matron had to be appointed and, since the 'General Rules for Gaols' specified that both the governor and the matron had to sleep in the gaol, it was usual for the governor's wife to be appointed the matron to ensure the moral standards of the day were upheld. Consequently, Mary Gee was appointed matron at the Sandhurst Gaol. ${ }^{16}$

Under the 'General Rules for Gaols' the governor was responsible for the administration of the gaol and the senior turnkey was responsible for the health and care of prisoners and the activities of other gaol staff. Matrons accompanied male staff whenever they were in the female areas of the gaol and a visiting justice was appointed to visit the gaol on a weekly basis to ensure that all of the regulations were enforced. ${ }^{17}$

The gaol staff comprised the governor, senior turnkey, matron and two turnkeys until about 1858 when four more turnkeys were appointed..$^{18}$ The 'General Rules for Gaols' were particularly strict about the responsibilities of turnkeys to ensure that they were beyond reproach. They were to act with decorum and morality, swearing or improper language was forbidden and gambling and card playing was strictly prohibited. They were not to visit public houses regularly or use tobacco in any form, and alcoholic intoxication would bring dismissal. Intimacy or friendship with the friends or relatives of prisoners was also strictly forbidden. ${ }^{9}$

The stockade was a cheap temporary structure, and so was the accommodation for the gaol staff. Gee and his wife lived in a quite inadequate hut in the gaol and the rest of the staff lived nearby in tents. In March 1856 the visiting justice reported that the turnkeys had been living in tents for two years and they had become so dilapidated that they hardly kept out the weather. The government was slow to replace them but a gale at Sandhurst eventually blew them down so they had to be replaced. Approval to build new staff quarters was not given until September 1857.20

The prison population was rarely stable because there were so many people on short sentences or awaiting trial. There were usually between 30 and 40 inmates and rarely more than 10 women. ${ }^{21}$ People convicted of relatively minor offences stayed at the Sandhurst stockade and most serious offenders were taken down to Pentridge Gaol where there were better facilities in which to house them. ${ }^{22}$

Not all the people in the gaol were what we would now call criminals. There were many destitutes people because vagrancy was a crime and there were also debtors and lunatics. ${ }^{23}$ Debtors were sent to prison to stop them from running away from their creditors and lunatics were sent there because there was really nowhere else to send them to keep them out of the way. Once inside the gaol there was little to separate the different kinds of prisoners and one of the tasks given to convicts was to take care of the lunatics. ${ }^{24}$ 
BEFORE I NOW

Vol. 1 No. 1
Children were occasionally sent to gaol. Usually they were with their mothers who had been convicted of a crime like vagrancy, but some were sent there for being themselves vagrants. Thirty-one children passed through the Sandhurst gaol in $1862 .{ }^{25}$

Prisoners were locked away in one of the gaol's four cells every night. There was no sewerage so they took in buckets and one of the first jobs every morning was emptying them. ${ }^{26}$ Prisoners who did the cooking were also let out early in the morning to prepare breakfast. The government had a scale of rations for various classes of prisoners, including men on hard or light labour, women and children. The amount varied for each class but they were all served the same limited fare - maize or oaten meal, bread, meat, potatoes, sugar and salt. The only variation was for the babies of women in the goal who were also allowed milk. ${ }^{27}$

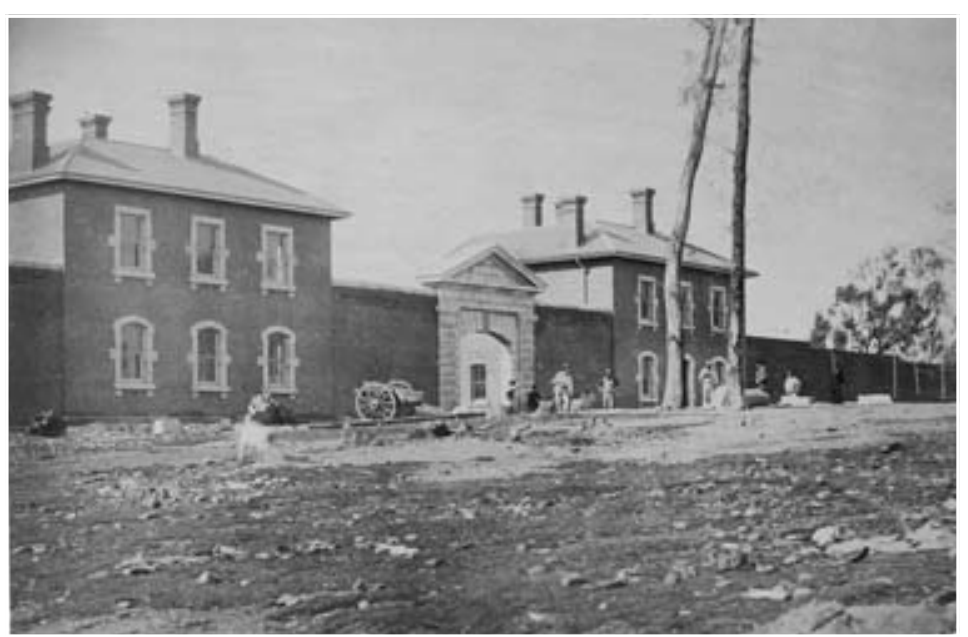

Benjamin Pierce Batchelder. Bendigo Gaol [picture], 1861.

SLV Picture Collection, b47320.
Prisoners were expected to work. It helped them pay for the cost of keeping them, it kept them busy and, for those sentenced to 'hard labour' it was punishment. The regulations stipulated that 'hard labour' meant breaking a cubic yard of rock a day - a useful occupation when crushed rock was used in making roads, bridges and buildings. Other work could include working on roads or other government projects, but that was only possible when there were enough guards to look after prisoners outside the gaol walls. As a result, most work was done inside the gaol. Regular jobs included whitewashing the gaol and maintaining its yards, and many hours were spent cooking, cleaning and looking after the sick and insane. Women prisoners were given the jobs of washing, cleaning and sewing. Another regular job was shaving and cutting prisoners' hair. All prisoners had to have their hair cut at least once a month and those who had been convicted had their hair cut short and kept that way. ${ }^{28}$

Gaol staff could punish minor acts of disobedience, but visiting justices were responsible for enforcing more severe discipline: the punishment for insubordination was one month's further imprisonment with hard labour; for using obscene and improper language to the governor, two or three months hard labour; for bringing tobacco and matches into the prison, a further month in gaol; for attempting to escape, a sentence of six months hard labour in the Melbourne Gaol; fora more extreme escape attempt, two years further imprisonment. ${ }^{29}$

Escapes and attempted escapes were not common but they occurred often enough to keep gaol staff vigilant. One afternoon a sudden heavy shower distracted the guards sheltering in their boxes and a prisoner used the opportunity to climb to the top of the stockade wall unobserved. However, the noise he made when he fell to the ground outside alerted the guards and they had him covered before he got any further. Other escapes were more carefully thought out and only prevented through diligence and experience. When Governor Gee carefully inspected the log cells in December 1855 he found logs had been almost cut through in two places but the cuts had been disguised by filling them with grease and dirt. After a major search the staff found two knives 
that had been fashioned into saws hidden under the cell floor. ${ }^{30}$

Even a moment's inattention could lead to trouble. The stockade had been built around the police lock-up so while the gaol staff were responsible for everything in the gaol, the police were responsible for the lockup. In January 1857 the police stored some confiscated 'sly grog' in their lock-up and then also put in a woman they had arrested. She soon found the grog, helped herself to it and started passing it to prisoners in the yard outside. The first Gee knew about it was when he found drunk women in the gaol yard and then discovered the male prisoners were also drunk and had taken on an angry mood. The guards were unable to control them so Gee called the local magistrate who tried to subdue them. He received only abuse for this efforts so he called in the local military force and the sight of armed Redcoats was enough to quell the disturbance. There was an official inquiry and, although none of the gaol staff were found responsible, a new police lock-up was soon built outside the stockade walls. $^{31}$

\section{The Chinese on the goldfields and in gaol}

In 1854 there were 4,000 Chinese migrants on the Australian goldfields and by the middle of 1855 this figure had increased significantly to 17,000. When the population of the Municipality of Sandhurst was counted in 1857 there were about 2,000 Chinese in the population of $12,159.32$

Political and economic chaos in the south of China around the Guangdong (Canton) Province had forced large numbers of people into poverty and misery so news of the gold discoveries in Victoria held out the possibility of some relief. Thousands of young Chinese men came to Victoria in the hope of being able to support their families at home through their success on the goldfields. They called the goldfields, and Bendigo in particular, Dai Gum San (The Big Gold Mountain).

Unlike most Europeans who came to the goldfields individually or in small groups, Chinese men came in larger groups based on families, clans and districts. They came on chartered boats, usually paid for by others so they had to pay off that debt before they could work for themselves. Europeans quickly became suspicious of the Chinese; they spoke a different language, acted differently, wore different clothes and usually kept the company of their own kind. On the other hand, the young Chinese men who were mainly farmers, found European languages and customs just as alien and strange, creating a gulf between the two groups on the goldfields. As a result there were many misunderstandings and a strong hatred developed against the Chinese that affected Australian society for over a century.

Most Chinese thought of themselves as members of their families and clans first and individuals second. They came to Dai Gum San to help their families by sending money home and to do that they suffered years of hard work and loneliness, separated from their homes and their families. They expected to return home one day when they had made their contribution to their family from far away.

On the whole the Chinese were quiet, respectful and hard working but Europeans saw large groups of Chinese men working together on the goldfields, saw their apparently close-knit communities and saw them as competition. The hostility this generated led to political pressure to control them and keep them out. One result was introduction of an annual Chinese residence tax of $£ 1$. Another measure was a tax of $£ 10$ on all Chinese who arrived in Victoria, but this did little to halt the flow because they soon discovered there was no tax in South Australia, and so they landed there instead. From 
BEFORE I NOW

Vol. 1 No. 1

Robe near the border with Victoria and from Adelaide further away ship loads of newly arrived Chinese made their way to the Victorian goldfields in snaking lines of men in single file, trotting across the countryside.

Since Europeans knew little about the Chinese they made the mistake of thinking they were all the same. But that was not so. They came from a populous and diverse area of China so there was a great diversity of customs and dialects. As a result, when they came to the Victorian goldfields they tended to work in the same cultural groups and live in separate camps. There was plenty of opportunity for disputes between the groups but when Europeans saw Chinese men arguing they simply thought they were naturally argumentative, difficult to get along with and hard to control.

These problems were made worse by the European belief that the Chinese were naturally inferior. It was seen as the European's right, even duty, to dominate and control the Chinese on the goldfields. Animosity towards the Chinese became so great that the government was forced to appoint 'Protectors' to help smooth relations with the Chinese, but suspicion and animosity became ingrained in the European community. ${ }^{33}$

All these attitudes showed up in the justice system on the goldfields. While the Chinese tended to settle many conflicts well away from the police and the courts, they did become involved on many occasions. Common stereotypes about the criminality of the Chinese, that they were naturally thieves, sly, and impossible to control, also brought them to the notice of the law while the inability of poor Chinese to pay the residence tax also often led them to the courts.

In the Sandhurst stockade all the Chinese prisoners were kept in one cell and they used the women's exercise yard. ${ }^{34}$ This kept the Chinese men away from European men to prevent trouble but this arrangement also highlighted a belief that Chinese men were lower in the social order, closer to women than real men. Keeping Chinese men together also promoted trouble because it sometimes put together men from opposing groups. This friction, that the Europeans found incomprehensible, gave the Chinese a bad reputation that led to them being treated differently, so when the new gaol at Beechworth with individual cells was opened the first prisoners to go into it were the Chinese so they could be separated to allow the authorities to 'maintain better order and discipline among them'. ${ }^{35}$

Gaol authorities also showed the same ignorance of Chinese customs when they cut the hair of prisoners. By custom and law, Chinese men had to grow a queue (or pigtail) but when they were convicted in Sandhurst Gaol their hair was cut in keeping with the 'General Rules for Gaols'. This instantly marked them as criminals to police and the public alike.

\section{Sandhurst's Stone Gaol}

By 1857 Victoria's prison population had increased significantly and its gaols were again becoming overcrowded. In addition, the stockades that had been erected quickly a few years earlier were no longer considered satisfactory. In late 1857 a board was created to investigate the matter and recommend a plan for the erection of future gaols. ${ }^{36}$

The people of Sandhurst thought poorly of their gaol. The log cellblock in the stockade was a structure 56 feet long and 15 feet divided into four separate cells 13 or 14 feet long by 15 feet wide. The ceiling was no more than 6 feet high and only 5 feet 6 inches high in one cell. There was little lighting or ventilation and as many as 21 men were packed into each cell. Reports by gaol visitors always remarked that it was as 
clean and healthy as possible but that the accommodation was 'wretched' and 'unfit for any purpose'. Governor Gee was praised for achieving so much for the prisoner's health and well-being in such appalling conditions but it was obvious that a large and populous district like Sandhurst deserved something better. ${ }^{37}$

In 1858 the government decided to built new, modern gaols in Victoria and the architects, Coote and Anderson, were commissioned to draw up plans and specifications for them. The plans for the new gaol at Sandhurst became the basis for other country gaols, particularly the new Beechworth gaol. ${ }^{38}$

These new gaols incorporated the latest ideas about how prisoners should be treated that came from Britain, America and prisons in Tasmania and Norfolk Island. Before the early years of the 19th century, prisons, as they later developed, did not exist in Britain. Instead, punishments included brutal corporal punishments such

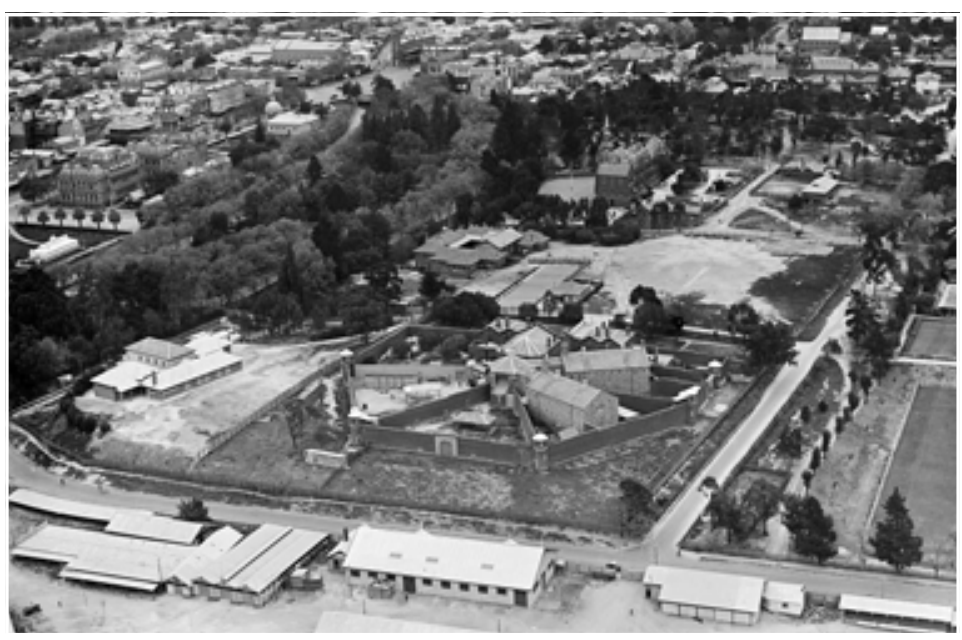

Charles Daniel Pratt and Airspy. Bendigo [picture], 1929.

SLV Picture Collection, H91.160/1744. as floggings, execution or transportation to the colonies. The prisons and hulks that did exist were appalling places where those awaiting trial or punishment were kept, along with debtors, vagrants and lunatics.

The primary purpose of these new prisons was to 'create a wholesome terror' in the minds of people likely to commit crimes and secondly to help convicts reform their criminal ways. ${ }^{39}$ The new penal philosophy was called 'separation' and based on the idea that if prisoners were kept in total seclusion they could not be influenced by other criminals and they would be forced to think about their criminal activities and thus be encouraged to reform. A new gaol design, called a 'panopticon', was created to treat prisoners in this way. It evolved into an arrangement of cellblocks two or three stories high with thick walled cells, one cell for each prisoner, in which they would be completely cut off from the outside world. The blocks were linked to a cental circle from which Prison Officers could observe everything prisoners did while they were outside their cells. This shape also made it possible to construct exercise yards in which prisoners walked up and down without seeing anyone apart from the guard. The first panopticon prison was completed at Pentonville in Britain in 1842 and after that similar prisons were constructed around the world, while existing prisons were converted to emulate this design. ${ }^{40}$ Panopticon gaols were expensive to build but they costed little to run because the prisoners could be fully controlled by only a few staff.

The first panopticon gaol in Victoria was built at Pentridge and put into use in August 1859. Prisoners were locked in their cells twenty-three hours of the day, unable to hear or see anything outside. To ensure absolute quiet, cell doors and walls were so thick that no sound could penetrate and the warders outside the cells walked on carpet in slippers so they would make no sound prisoners could hear. There was nothing for prisoners to do in this prison but think. Even the chapel was fitted with individual cubicles so prisoners were separated from each other there. Authorities quickly reported that this new treatment method made even the most difficult prisoners submissive and controllable. ${ }^{41}$ 
BEFORE / NOW

Vol. 1 No. 1

In the new Bendigo gaol the only significant variation from the panopticon ideal was a number of linked first floor cells that were probably provided to accommodate debtors who did not require the strict separation of other prisoners. The panopticon design also had the practical advantage that cell blocks around a central circle provided better lighting and ventilation for every cell. However, unlike the new gaol at Pentridge, the cells in country gaols did not have water or sewerage so prisoners continued to have cell buckets that they emptied when their cells were opened in the morning. ${ }^{42}$

The new country goals were usually located so they were easily visible to people in the town to remind them what happened to criminals, and to deter them from crime. In Beechworth the new gaol was located on land looking down over the town and at Castlemaine the gaol dominated the town from its location behind and up from the railway station. At Sandhurst the new gaol was located at the end of the government camp reserve overlooking the town. These locations meant that although the country gaols had the same basic buildings they were arranged differently. At Beechworth, where the land sloped gently away from the town, there was plenty of space so the gaol was laid out symmetrically with generous yards. The location of the Castlemaine gaol on the crest of a hill forced it to be more cramped with truncated buildings. At Sandhurst the gaol was located on the edge of a steep rise so it was necessary to build the cell blocks facing away from the town with the kitchens and stores located under the western cell block. The government tried to use local materials where it could so the gaol at Beechworth was constructed of granite and the Sandhurst gaol was made of sandstone and brick. ${ }^{43}$

The construction of Sandhurst gaol was only part of a massive project to give Victoria modern goals and, by 1864, the Colony had nine virtually new gaols. The most expensive was a new gaol in Melbourne - now called the 'Old Melbourne Gaol' (which had cost $£ 122,628$ by 1864). There were also gaols at Beechworth ( $£ 46,375)$, Castlemaine $(£ 43,220)$, Sandhurst $(£ 44,103)$, Geelong $(£ 48,257)$, Ararat (£23,538), Maryborough $(£ 23,557)$, Ballarat $(£ 43,126)$ and Portland $(£ 2,981)$. Together with the cost of developments at Pentridge, the total cost of the project was over half a million pounds. ${ }^{44}$

Sandhurst's new gaol was to be built in two stages, the inner buildings and then the outer ones including the walls. This allowed the builders to have easy access to the inner building before it was enclosed by large walls.

Plans for the new gaols were ready in late 1858 and newspaper advertisement seeking tenders appeared in December. The government set aside about $£ 14,500$ for the first stage of work at Sandhurst, £14, 300 for Beechworth and £11,743 for Castlemaine. When the tenders were opened all were well above the estimated costs and the lowest tender for Sandhurst was at £22,500. Undeterred, the government decided to accept the lowest tenders, so long as the cost of works was reduced to the amount it had budgeted for. After negotiations, in February 1859 James McKenzie of Sandhurst was awarded the contract to construct the first stage of Sandhurst Gaol for the sum of $£ 14,491.45$

McKenzie began work on the inner buildings around March 1859 and they were beginning to take shape by September. Granite was the main material used in the buildings, from Big Hill to the south of Sandhurst where a big railway tunnel was then being built. Observers noted that, unlike any other government buildings they had seen, this one appeared to lack symmetry. ${ }^{46}$ Although the contract specified granite for 
the building's foundations the contractor used cheaper 'freestone', perhaps to recoup some of the money he had lost when his tender was reduced. The government inspector noticed the substitution and the value of the contract was reduced by $£ 103$. The contractor and the government were still haggling about it when the job was completed around May 1860.47

The contract for the second stage of the project, including quarters for the governor and other staff and the walls, was awarded to James Duncan in September 1860. As had happened with the first stage, tenders were higher than the government was prepared to accept and Duncan was asked to agree to a reduced price. Duncan refused so the government kept his deposit and offered the job to the next tenderer on the list, William Teal, for an estimated cost of $£ 13,700.48$ Prisoner labour was used to demolish existing buildings including parts of the old stockade wall and police stables to make way for the new work. ${ }^{49}$

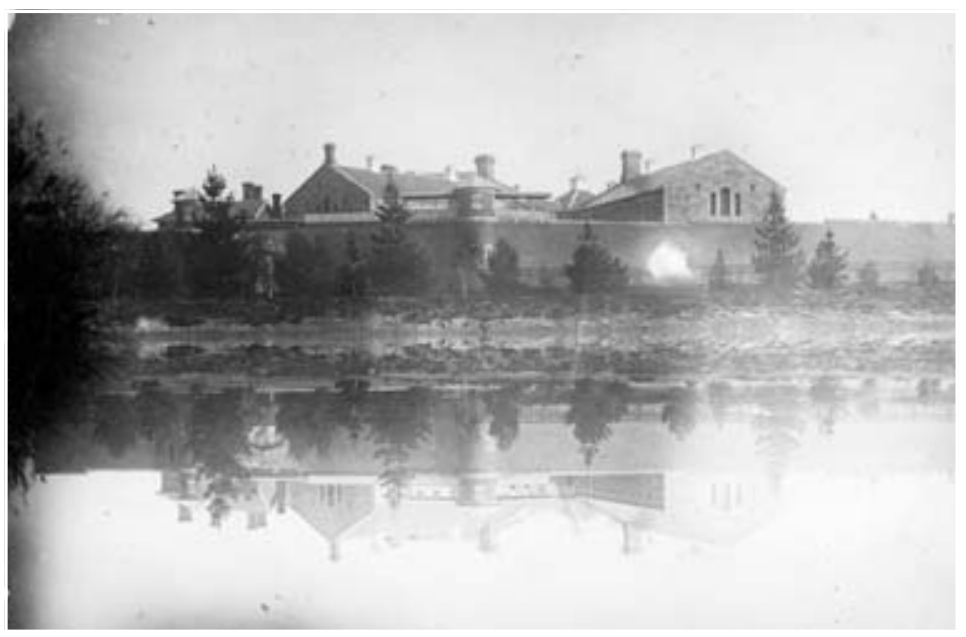

HM Prison Bendigo [picture], c1900.

SLV Picture Collection, H42553/1.

The work did not go smoothly and there seems to have been continual bickering between Teal and the government about the details of the work, a couple of major changes and structural failures. The gaol walls were made of squares of granite rubble faced in brick, perhaps because of the lack of suitable local stone, and initial plans to use solid granite in the foundations were changed to granite rubble to help save money. Perhaps this had something to do with part of the wall collapsing in early December when changes had to be made to ensure the same thing didn't happen again. In late November gables also gave way, necessitating further changes. ${ }^{50}$ By June 1861 the work was almost completed and instructions were issued that there could be no further changes to the plans. ${ }^{51}$

In mid August 1861 the government sent Teale a list of several tasks which needed to be done to complete the contract and everything was ready for prisoners to move in by the end of September. On 7 October 1861 the new gaol at Sandhurst, along with those at Ararat and Castlemaine, were declared 'public gaols'. On 14 October 61 prisoners, including several debtors, were moved into the new gaol and the gates closed for the first time behind them. ${ }^{52}$

Most of the work had now been completed, but much still remained to be done. Most important was construction of the chapel and offices in the gaol forecourt and the contract for that work was awarded to Robert White during 1864 for a little over $£ 2000 .{ }^{53}$ The kitchen under the western wing had to be completed and a boiler was installed in $1863 .{ }^{54}$ In 1862 extra work was done to repair and complete the staff accommodation and extra works had to be done to the front and side walls. ${ }^{55}$ Beginning around March 1864 almost $£ 200$ had to be spent on major repairs to the gaol's foundations. ${ }^{56}$ Around this time a tunnel was built from the gaol to the nearby court building so there was no danger of inmates escaping on their way to and from the court. (Later, when a new Supreme Court building was opened on Pall Mall in 1896, the tunnel was closed off. $)^{57}$ With the work virtually completed by late 1864 the 
BEFORE I NOW

Vol. 1 No. 1

Sandhurst Gaol was proclaimed once again, with the gaols at Ballarat, Castlemaine, Maryborough, Melbourne, Portland and Sale. ${ }^{58}$ This signalled the end of Victoria's great gaol building effort and the government shifted its focus to building asylums for the insane, that would take pressure off the gaols where lunatics had previously been sent.

\section{Conclusion}

The stone edifice of the Bendigo Gaol stood, looking down over Bendigo as the city grew and changed over the following century and a half, its heavy stone architecture withstanding changes in government policy, town planning and public attitudes. It was simply too big and too solid to be easily converted to meet the needs of changing times.

The peak of the gold rushes had passed by the mid 1860s and populations declined and stabilized so that the peak demand that gaols like the one that had been built for Bendigo were not reached again. By the 1920s, the goal population was under twenty prisoners so much of the building stood empty. During the First and Second World Wars the goal was used to accommodate military prisoners and after the second war it remained empty until it was refurbished and reopened in 1953. By then the century old buildings could no longer accommodate new ideas and attitudes about the treatment of prisoners and the Victorian government began building new gaols on a less grand but more suitable scale. Nevertheless, Bendigo Gaol remained in use until 2004, serving for its final few years as an establishment specializing in the rehabilitation of prisoners with drug related problems.

When it was finally closed as a government goal on 20 December 2004 it was the last of Victoria's gold rush stone gaols to accommodate prisoners. It is currently known as the Sandhurst Goal, houses a large community theatre and hosts guided tours for those curious about its penal past. However, it's sheet size, bulk and location means that it is likely to remain as a visible memorial to the early planners and builders of western civilization in Australia and how they thought about and treated their fellow humans, for centuries yet to come.

\section{Leigh Edmonds | Honorary Research Fellow \\ CRCAH, Federation University Australia \\ Email: leighedmonds01@gmail.com}

Leigh Edmonds is a consulting historian, an Honorary Research Fellow of CRCAH and a member of the Professional Historians Association. His primary interest is in the history of technology, particularly as it applies to white settler colonies such as Australia. Leigh is the author of H.M. Prison Beechworth : the end of an era, 1856-2004, Beechworth, Vic. : Corrections Victoria, 2006. ISBN: 0646455591. More recently he has published histories of Haileybury College (A Good School), the Australian Taxation Office (Working for All Australians) and two volumes of a history of civil aviation in Australia (Australia takes Wing and Stability in Flight)'. 


\section{Notes}

1. Frank Cusack, Bendigo, a history (Revised Edition), Bendigo, 2002, p.23.

2. Cusack, Bendigo, a history, p.46.

3. George Mackay, Annals of Bendigo, 1868-1891 (Bendigo [Vic.]: Mackay \& Co.), 1914, p.9.

4. Cusack, Bendigo, a history, p.80 and p.116.

5. Annals of Bendigo, p.29.

6. Bendigo Advertiser, 5 May 1856.

7. Annals of Bendigo, p.78.

8. Geoffrey Serle, The Golden Age, a history of the Colony of Victoria, 1851-1861, Melbourne, 1963, p86.

9. I S Kerr, Out of Sight, out of mind: Australia's places of confinement 1788-1988, Adelaide, 1990, p.73.

10. Public Records Office of Victoria (PROV), VPRS 1189, unit 63, item 53/117.

11. Kerr, Out of Sight, out of mind, p.71 and PROV, VPRS 1189, unit 15.

12. PROV, VPRS 1189, unit 65, item 53/265.

13. PROV, VPRS 1189, many items in several units covering 1853.

14. General Rules for Gaols, Pursuant to the Provisions of the Act of the Lieutenant Governor and the Legislative Council of Victoria, 10 Victoria No 32, PROV, VPRS 1189, unit 417, item 58/4448 and Kerr, Out of Sight, out of mind, p.79.

15. Victorian Government Gazette, 20 December 1853.

16. PROV, VPRS 538, unit 2, item 2.

18. PROV, VPRS 1189, unit 415, item 57/8857 and unit 419 item 58/10232.

20. PROV, VPRS 974, unit 4 and VPRS 1189, unit 409.

21. PROV, VPRS 1189, these figures are taken from the Visiting Justice's monthly reports and from a summary of the weekly gaol occupancy from January to October 1856.

22. PROV, VPRS 1189, there are numerous authorities for transfer of prisoners from all country gaols to Melbourne scattered through the items in this record series.

23. PROV, VPRS 1189, unit 417, item 58/4448.

24. Peter Lynn and George Armstrong, From Pentonville to Pentridge: a history of prisons in Victoria, Melbourne, 1996, p.137, Annals of Bendigo, p.78 and Bendigo Advertiser, 29 September 1856 and 29 November 1859.

25. PROV, VPRS 1189, unit 66 item 53/409, unit 412 item 57/915 and unit 441 item 62/6707.

26. PROV, VPRS 975, unit 1 and VPRS 1189, unit 432, item $61 / 5591$ which gives some hints about the routine of the gaol.

27. Victorian Government Gazette, 1859, p.2788.

28. PROV, VPRS 1189, a large number of monthly work returns, for example unit 415 items 57/6902, 57/6877, 57/7883 and 57/7375 and unit 417, item 58/4448.

29. These examples are taken from the visiting justices monthly reports in 1856. PROV, VPRS 1189, units 409, 410 and 411.

30. David Horsfall Ephemera collection, Bendigo Library.

31. Bendigo Advertiser 19 January 1857, 20 January 1857 and 2 December 1938 and Annals of Bendigo, p.29.
The Advertiser complained that the inquiry was not made public but the report of the inquiry can be found in PROV, VPRS 1189, unit 412, item 57/1420.

32. Annals of Bendigo, p.29 and Brian Barrow, Chinese \& The Law, Bendigo, 2001, p.21.

33. For examples see Annals of Bendigo, p.26 and p.61.

34. PROV, VPRS 1189, unit 432, item 61/5591.

35. PROV, VPRS 1189, unit 426, item 60/5700

36. Bendigo Advertiser 20 January 1857 and PROV, VPRS 975 , unit 4, entry 57/3336.

37. Bendigo Advertiser, 3 January 1857.

38. PROV, VPRS 975 unit 3 and VPRS 1189, various units for 1858 and 1859.

39. Annual Report, 1853.

40. Lynn and Armstrong, From Pentonville to Pentridge, pp.6-7.

41. Lynn and Armstrong, From Pentonville to Pentridge, pp.52-54.

42. Lynn and Armstrong, From Pentonville to Pentridge, p.78 and Kerr, Out of Sight, out of mind, p.37 and pp.62-63.

43. Kerr, Out of Sight, out of mind, p.19, p.76 and pp.80-81

44. Kerr, Out of Sight, out of mind, p.82.

45. Victorian Government Gazette, 1858 p.2640 and PROV, VPRS 974, unit 1, 19 and 29 December 1858, VPRS 975, unit 2, entry 583902 and 58/4115 and VPRS 1397, unit 1.

46. Bendigo Advertiser, 24 September 1859.

47. PROV, VPRS 69, unit 9, entry 1860, VPRS 975 unit 5 entry 60/1958 and VPRS 980, unit 1, entry 60/290.

48. Victorian Government Gazette 1860, p.1884 and PROV, VPRS 974, item 2, entries 12/9/1860 and VPRS 975, unit 2 entry 60/2957.

49. PROV, VPRS 69, unit 10, 1860.

50. It is uncertain whether the bricks used in the walls were made in Melbourne or Bendigo. Sample bricks were sent up from Melbourne but since Teale would have bought the bricks rather than the government, there is no official record of where they came from. PROV, VPRS 980, unit 1 , entries 60/636, 60/683, 60/703 and $60 / 716$.

51. PROV, VPRS 980, unit 1 , entries 60/641, 61/267 and $61 / 344$.

52. Victorian Government Gazette 1861, p.1912, PROV, VPRS 69, unit 10, 1860, VPRS 975, unit 7, entries 61/2073, $61 / 2307$ and 61/3065, VPRS 980, unit 2, entry 61/606, VPRS 1189, unit 434, item 61/7966 and Bendigo Advertiser, 15 October 1861

53. Victorian Government Gazette 1864 p.76 and p.2072.

54. Victorian Government Gazette 1863, p.2419 and PROV, VPRS 69, unit 2, entry 2861,

55. Victorian Government Gazette 1864, p.681 and PROV, VPRS 69, unit 14 entry 1864 and unit 117, entry 162.

56. PROV, VPRS 69, unit 14, entry 1864 and VPRS 980, unit 3, entries for 1, 5 and 15 February 1864.

57. David Horsfall Ephemera collection, unpublished historical notes.

58. Victorian Government Gazette 1864, p.2408. 